\title{
Trends and challenges in soil research 2009: linking global climate change to local long-term forest productivity
}

\author{
Zhihong Xu • Chengrong Chen • Jizheng He • Juxiu Liu
}

Received: 22 January 2009 / Accepted: 23 January 2009/Published online: 12 February 2009

(C) Springer-Verlag 2009

Long-term impacts of global climate change (GCC) and local forest management on important biogeochemical cycles of carbon (C) and nutrient cycling in the soil-plant ecosystems are complex and difficult to assess (Oren et al. 2001; Reich et al. 2006; Xu and Chen 2006; Davidson et al. 2007; Chen and Xu 2008; Clark and Tilman 2008; Xu et al. 2008a, b), particularly under gradually and continuously rising atmospheric carbon dioxide concentration $\left[\mathrm{CO}_{2}\right]$ and warming in the real world with multiple limiting factors (Hui et al. 2002; Savard et al. 2004; Büntgen et al. 2007; Feeley et al. 2007; Engelbrecht et al. 2007). In this editorial, as a part of the journal editorial series (Förstner and Salomons 2008), we highlight the recent developments and applications of advanced stable isotope, nuclear magnetic resonance (NMR), and biomolecular techniques in an integrated approach with innovative rhizosphere and tree ring methods, for improving our understanding and

Z. Xu $(\bowtie) \cdot$ C. Chen

Centre for Forestry and Horticultural Research,

School of Biomolecular and Physical Sciences,

Griffith University,

Kessels Road 170,

Nathan, Queensland 4111, Australia

e-mail: zhihong.xu@griffith.edu.au

J. He

State Key Laboratory of Urban and Regional Ecology,

Research Centre for Eco-environmental Sciences,

Chinese Academy of Sciences,

Shuangqing Road 18,

Beijing 100085, China

J. Liu

South China Botanical Garden,

Chinese Academy of Sciences,

723 Xingke Road,

Guangzhou 510650, China management of above- and below-ground $\mathrm{C}$ and nutrient cycling processes in forest ecosystems, particularly in response to GCC and local management practices as well as mitigation/adaptation strategies. The opportunities and limitations of these techniques for investigating $\mathrm{C}$ and nutrient cycling processes in forest ecosystems are discussed, in the context of both short- and long-term impacts on the aboveand below-ground processes. Improved understanding and knowledge of environmental fingerprints of the biogeochemical cycles embedded in tree rings can be effectively used to account for long-term forest productivity and $\mathrm{C}$ stocks at local, regional, and global scale in response to the future GCC and management options.

\section{Global climate change and forest management}

Over the last century, atmospheric $\left[\mathrm{CO}_{2}\right]$ has increased globally by nearly $30 \%$ and temperature by approximately $0.6^{\circ} \mathrm{C}$, and these trends are projected to continue more rapidly (Xu and Chen 2006), particularly with more extreme climatic conditions. The impacts of GCC on future structure, composition, and $\mathrm{C}$ and nutrient cycling in forest ecosystems deserve particular attention and further research. Little is known about the impacts of GCC and forest management on plant-soil-microbe interactions. Plant-soil-microbe interactions mainly occur in the rhizosphere, which is defined as the zone of soil that is affected by the root activity of any plant species. The rhizosphere is suggested here as the "hotspot" for plant-soil-microbe interactions - the most chemically and biologically active microsite in soil (Seguin et al. 2004) -and represents a complex integrated ecosystem. The ecology in the underworld, particularly below-ground processes and their interactions with above-ground processes, has been high- 
lighted in the Science (Volume 304, 1613-1637, 11 June 2004). There is growing need for improving the understanding and management of important below-ground processes. Understanding rhizosphere $\mathrm{C}$ and nutrient cycling processes in relation to rising $\left[\mathrm{CO}_{2}\right]$ and temperature is crucial for predicting the response of forest ecosystems to GCC (Xu and Chen 2006; Hyvönen et al. 2007).

Annual tree ring width measurements can be used to study tree growth indices of different species at scales from years to decades/centuries in seasonally distinguished growth environments, particularly in response to the changing climate and historical episodes (Duquesnay et al. 1998; Penninckx et al. 1999; Saurer et al. 2004; Savard et al. 2004; Büntgen et al. 2007). Together with tree ring growth measurements, tree ring stable isotope (particularly ${ }^{13} \mathrm{C},{ }^{18} \mathrm{O}$, and ${ }^{15} \mathrm{~N}$ ) compositions (Duquesnay et al. 1998; Elhani et al. 2003; Saurer et al. 2004; Savard et al. 2004; Treydte et al. 2006; Helliker and Richter 2008) and element concentrations (Penninckx et al. 1999; Drouet et al. 2005a, b) may be used to reconstruct past, long-term climate change (particularly atmospheric $\left[\mathrm{CO}_{2}\right]$, temperature, and rainfall) in different regions of the world. These methods can also be used to assess the impacts of historical episodes (e.g., acid deposition and fertilization) on longterm productivity and biodiversity of forest ecosystems (Horz et al. 2004; Reich et al. 2006; Davidson et al. 2007; Magnani et al. 2007; Clark and Tilman 2008). Hence, these environmental fingerprints of the biogeochemical cycles embedded in tree rings can be effectively used to account for the long-term forest productivity and $\mathrm{C}$ stocks at local, regional, and global scale in response to the future GCC and management practices.

\section{Rhizosphere study techniques}

The quantitative understanding of rhizosphere processes is poor since the rhizosphere is a difficult system to physically sample and manipulate (Xu and Chen 2006). Currently there are two commonly used methodologies to physically separate rhizosphere soil from bulk soil. One is the handshaking method (Seguin et al. 2004). The second approach involves direct (in situ) sampling of soil adjacent to roots by thin sectioning and/or placement of different sized mesh materials around roots (Xu and Chen 2006). It is challenging, but necessary to develop sampling techniques and protocols building on the promising hand-shaking method (Seguin et al. 2004), which takes into account the spatial and temporal variability in the rhizosphere of forest ecosystems. In addition, modeling of rhizosphere will be able to upscale the uptake of nutrients to the whole plant scale (Darrah et al. 2006).

\section{Microbiological methods}

Soil microbial properties such as biologically regulated nitrogen $(\mathrm{N})$ transformations, microbial biomass $\mathrm{C}, \mathrm{N}$, and phosphorus $(\mathrm{P})$, respiration, metabolic quotient, and enzyme activity can be very sensitive to GCC and forest management (Xu and Chen 2006; Chen and Xu 2008; Huang et al. 2008a, b, c; Pan et al. 2008; Xu et al. 2008a, b). However, information about the impacts of GCC and forest management on soil microbial properties is rather limited (Chen et al. 2004; Chen and Xu 2006; Burton et al. 2007a, b; Zhao et al. 2007; He et al. 2008a, b). Conventional culture-dependent methods have been used for the measurement of soil microbial composition for more than a hundred years. Nevertheless, only $0.1-1 \%$ of soil microorganisms are accessible by these approaches.

\section{Biomolecular techniques}

Recent advances in biomolecular techniques make it possible to apply culture-independent and DNA/RNA nuclear acid-based techniques to analyze the targeted sequences of bacterial or fungal DNA directly extracted from soil (He et al. 2005a, b, 2006; Bastias et al. 2006a, b; $\mathrm{Xu}$ and Chen 2006; Bastias et al. 2007; Ge et al. 2008a, b; He et al. 2008a; Zhang and $\mathrm{Xu}$ 2008; Zheng et al. 2008). The determination of $16 \mathrm{~S}$ ribosomal RNA (rRNA) genes and 18S rRNA genes has proved most useful for investigating the diversity and composition of bacteria and fungi, respectively, since these molecules are composed of highly conserved regions and also of regions with considerable sequence variation. The applications of microbial functional genes (e.g., $p m o A$ and amoA) have greatly improved our understanding of the abundance and composition of specific groups (e.g., methanotrophs and ammonia oxidizers) of microorganisms involving in the biogeochemical cycling (Leininger et al. 2006; He et al. 2007; Shen et al. 2008; Zheng et al. 2008).

\section{Stable isotope and NMR techniques}

Stable isotope techniques are considered as a critical component in the studies of GCC (e.g., elevated $\left[\mathrm{CO}_{2}\right]$ ) and forest management on soil $\mathrm{C}$ and $\mathrm{N}$ dynamics (Blumfield et al. 2004; Xu and Chen 2006; Chen and Xu 2008; Huang et al. 2008b; Pan et al. 2008). Stable isotope techniques have been found to be a very powerful tool for advancing the understanding of important $\mathrm{C}$ and $\mathrm{N}$ cycling processes in terrestrial ecosystems (Xu et al. 1993a, b; Guinto et al. 2000; $\mathrm{Pu}$ et al. 2001, 2002; Blumfield et al. 2004; Pu et al. 2005; Huang et al. 2008b; Pan et al. 2008). Recent applications of 
stable isotope techniques to soil biological studies have resulted in significant advances in the understanding of soil microbial processes regulating the $\mathrm{C}$ and $\mathrm{N}$ cycling in terrestrial ecosystems. It is very exciting to see the combined use of stable isotope and biomolecular techniques in recent studies (Xu and Chen 2006), which have identified specific microorganisms that are actively involved in particular metabolic processes.

NMR techniques have been increasingly used in soil science, geochemistry, and environmental science (Mathers et al. 2000; Mao et al. 2002; Blumfield et al. 2004; Chen et al. 2004; Johnson et al. 2005; Xu and Chen 2006; Chen and $\mathrm{Xu}$ 2008). In particular, ${ }^{13} \mathrm{C}$ NMR has been widely used to improve the understanding of soil organic matter (SOM) quality and composition in relation to terrestrial $\mathrm{C}$ and $\mathrm{N}$ cycling processes. Natural abundance ${ }^{15} \mathrm{~N}$ crosspolarization/magic angle spinning NMR spectra of SOM have been obtained by Knicker et al. (1993), indicating that almost all signal intensity is in the chemical shift region assigned to peptide/amide N. In the first application of ${ }^{14} \mathrm{~N}$ NMR to soil humic acid (HA) studies, Mao et al. (2002) have discovered the surprising existence of nitrate- $\mathrm{N}$ in soil HA, with the HA nitrate-N closely related to soil $\mathrm{N}$ availability and rather responsive to ecosystem management. The advanced NMR techniques need to be assessed for their potential in improving the understanding of rhizosphere $\mathrm{C}$ and nutrient cycling, particularly when combined with stable isotope and biomolecular techniques (Knicker 2002).

\section{Tree ring technique}

Most terrestrial ecosystem studies (Oren et al. 2001; Reich et al. 2006; Xu and Chen 2006; Hyvönen et al. 2007; Piao et al. 2008) on GCC impacts have been undertaken over short periods $(<10$ years) with one or two factors of contrasting treatments (e.g., with and without $\mathrm{N}$ additions) and large step increases (e.g., ambient $\left[\mathrm{CO}_{2}\right] 350 \mathrm{ppm}$ and elevated $\left[\mathrm{CO}_{2}\right] 700 \mathrm{ppm}$ ). These would be very different from the real world with gradually rising $\left[\mathrm{CO}_{2}\right]$ and warming as well as changing rainfall patterns in the context of atmospheric deposition over periods from decades to centuries, particularly for forest ecosystems (Duquesnay et al. 1998; Saurer et al. 2004; Drouet et al. 2005b; Büntgen et al. 2007; Feeley et al. 2007). Tree ring growth (Duquesnay et al. 1998; Penninckx et al. 1999; Saurer et al. 2004; Savard et al. 2004; Büntgen et al. 2007), stable isotope composition (Duquesnay et al. 1998; Elhani et al. 2003; Saurer et al. 2004; Savard et al. 2004; Treydte et al. 2006; Helliker and Richter 2008), and element concentration (Penninckx et al. 1999; Drouet et al. 2005a, b) over decades or centuries can provide exciting opportunities to investigate the impacts of GCC and historical episodes (e.g., acid deposition and prescribed burning or wild fires) on important biogeochemical cycles of $\mathrm{C}$ and nutrients (Xu and Chen 2006; Gruber and Galloway 2008; Heimann and Reichstein 2008), underpinning the long-term tree growth and water-use efficiency (WUE) as well as biodiversity of forest ecosystems (Saurer et al. 2004; Savard et al. 2004; Büntgen et al. 2007; Engelbrecht et al. 2007; Clark and Tilman 2008). However, this type of research approach is not without significant problems and requires complementary short-term laboratory and field experiments to help tease out the complex interactions among multiple factors of gradual GCC (Duquesnay et al. 1998; Hui et al. 2002; Saurer et al. 2004; Büntgen et al. 2007; Feeley et al. 2007) and historical episodes (Savard et al. 2004; Magnani et al. 2007; Clark and Tilman 2008). While rising $\left[\mathrm{CO}_{2}\right]$ and atmospheric warming are well-recognized GCC phenomena (Davidson and Janssens 2006; Xu and Chen 2006), their long-term impacts on biogeochemical cycles, ecosystem productivity, and biodiversity can differ with locations and species/ ecosystems (Horz et al. 2004; Davidson and Janssens 2006; Büntgen et al. 2007; Feeley et al. 2007; Hyvönen et al. 2007) as well as historical episodes (Savard et al. 2004; Magnani et al. 2007; Clark and Tilman 2008), in the context of local rainfall, temperature, atmospheric deposition/air pollution, and soil fertility.

In addition, rising $\left[\mathrm{CO}_{2}\right]$ is expected to result in increased plant photosynthesis and reduced stomatal conductance, hence higher plant WUE and $\delta^{13} \mathrm{C}$ (Duquesnay et al. 1998; Prasolova et al. 2000, 2001; Xu et al. 2000; Saurer et al. 2004; Long et al. 2006; Hyvönen et al. 2007), but this can be counteracted by decreasing plant photosynthesis and $\delta^{13} \mathrm{C}$ due to acid deposition (Savard et al. 2004) and decreasing atmospheric $\delta^{13} \mathrm{C}$ from increasing fossil $\mathrm{CO}_{2}$ emissions (Keeling et al. 1979), respectively. Plant WUE and growth can be increased by elevated $\left[\mathrm{CO}_{2}\right]$ and $\mathrm{N}$ availability (Oren et al. 2001; Prasolova and Xu 2003; Xu et al. 2003; Prasolova et al. 2005; Long et al. 2006; Reich et al. 2006; Hyvönen et al. 2007; Magnani et al. 2007; Huang et al. 2008d, e, f), at least in the short term, but their longterm levels may be counteracted by age-related biologically declining trends (Duquesnay et al. 1998; Penninckx et al. 1999) and progressive nutrient limitations (Oren et al. 2001; Drouet et al. 2005a, b; Long et al. 2006; Reich et al. 2006; Hyvönen et al. 2007). The mobility of elements (Penninckx et al. 1999; Elhani et al. 2003; Drouet et al. 2005a, b; e.g., N) between adjacent tree rings and differences in stable isotope composition between components (Duquesnay et al. 1998; Elhani et al. 2003; Saurer et al. 2004; Treydte et al. 2006) of tree ring material (e.g., cellulose against whole tree ring material) can also pose problems in interpreting these ring data, with increasing margins of error. Furthermore, there are limited long-term records of local atmospheric $\left[\mathrm{CO}_{2}\right]$, 
temperature, rainfall, and acid deposition for many parts of the world and either re-constructed or global averages of these parameters would need to be used from ice core (Mayewski and Whitlow 1996; Etheridge et al. 1998) and tree ring data (Keeling et al. 1979; Duquesnay et al. 1998; Saurer et al. 2004; Treydte et al. 2006; Büntgen et al. 2007) for assessing the long-term impact of gradual GCC and historical episodes. These would need to be calibrated and tested by well-controlled and focused studies as well as sophisticated mathematical and ecosystem modeling across the diversified regions of the world.

\section{References}

Bastias BA, Huang ZQ, Blumfield T, Xu ZH, Cairney JWG (2006a) Influence of repeated prescribed burning on the soil fungal community in an eastern Australian wet sclerophyll forest. Soil Biol Biochem 38:3492-3501

Bastias BA, Xu ZH, Cairney JWG (2006b) Influence of long-term repeated prescribed burning on mycelial communities of ectomycorrhizal fungi determined by DGGE profiling of DNA from hyphal ingrowth bags. New Phytol 172:149-158

Bastias BA, Anderson IC, Xu ZH, Cairney JWG (2007) RNA- and DNA-based profiling of soil fungal communities in native Australian eculypt forest and adjacent Pinus elliottii plantation. Soil Biol Biochem 39:3108-3114

Blumfield TJ, Xu ZH, Mathers NJ, Saffigna PG (2004) Decomposition of post-harvest, ${ }^{15} \mathrm{~N}$-labelled hoop pine residues in subtropical Australia. Soil Sci Soc Am J 68:1751-1761

Büntgen U, Frank DC, Kaczka RJ, Verstege A, Zwijacz-Kozica T, Esper J (2007) Growth responses to climate in a multi-species tree-ring network in the Western Carpathian Tatra Mountains, Poland and Slovakia. Tree Physiol 27:689-702

Burton J, Chen CR, Xu ZH, Ghadiri H (2007a) Gross nitrogen transformations in adjacent native and plantation forests of subtropical Australia. Soil Biol Biochem 39:426-433

Burton J, Chen CR, Xu ZH, Ghadiri H (2007b) Soluble organic nitrogen pools in adjacent native and plantation forests of subtropical Australia. Soil Biol Biochem 39:2723-2734

Chen CR, Xu ZH (2006) On the nature and ecological functions of soil soluble organic nitrogen (SON) in forest ecosystems. J Soils Sediments 6:63-66

Chen CR, Xu ZH (2008) Analysis and behaviour of soluble organic nitrogen in forest soils. J Soils Sediments 8:363-378

Chen CR, Xu ZH, Mathers NJ (2004) Soil carbon pools in adjacent natural and plantation forests of subtropical Australia. Soil Sci Soc Am J 68:282-291

Clark CM, Tilman D (2008) Loss of plant species after chronic low-level nitrogen deposition to prairie grasslands. Nature 451:712-715

Darrah PR, Jones DL, Kirk GJD, Roose T (2006) Modelling the rhizosphere: a review of methods for 'upscaling' to the whole-plant scale. Euro J Soil Sci 57:13-25

Davidson EA, Janssens IA (2006) Temperature sensitivity of soil carbon decomposition and feedbacks to climate change. Nature 440:165-173

Davidson EA, de Carvalho CJR, Figueira AM, Ishida FY, Ometto JPHB, Nardoto GB, Saba RT, Hayashi SN, Leal EC, Vieira ICG, Martinelli LA (2007) Recuperation of nitrogen cycling in Amazonian forests following agricultural abandonment. Nature 447:995-998
Drouet T, Herbauts J, Demaiffe D (2005a) Long-term records of strontium isotopic composition in tree rings suggest changes in forest calcium sources in the early 20th century. Glob Change Biol 11:1926-1940

Drouet T, Herbauts J, Gruber W, Demaiffe D (2005b) Strontium isotope composition as a tracer of calcium sources in two forest ecosystems in Belgium. Geoderma 126:203-223

Duquesnay A, Bréda N, Stievenard M, Dupouey JL (1998) Changes of tree-ring delta C-13 and water-use efficiency of beech (Fagus sylvatica L.) in north-eastern France during the past century. Plant Cell Environ 21:565-572

Elhani S et al (2003) Inter-annual mobility of nitrogen between beech rings: a labelling experiment. Ann For Sci 60:503-508

Engelbrecht BMJ, Comita LS, Condit R, Kursar TA, Tyree MT, Turner BL, Hubbell SP (2007) Drought sensitivity shapes species distribution patterns in tropical forests. Nature 447:80-82

Etheridge DM et al (1998) Historical CO2 records from the Law Dome DE08, DE08-2 and DSS ice cores. Carbon Dioxide Information Analysis Centre, Oak Ridge National Laboratory, US Department of Energy, Oak Ridge, USA

Feeley KJ, Joseph Wright S, Nur Supardi MN, Kassim AR, Davies SJ (2007) Decelerating growth in tropical forest trees. Ecol Lett 10:461-469

Förstner U, Salomons W (2008) Trends and challenges in sediment research 2008: the role of sediments in river basin management. J Soils Sediments 8:281-283

Ge Y, He JZ, Zhu YG, Zhang JB, Xu ZH, Zhang LM, Zheng YM (2008a) Differences in soil bacterial diversity: driven by contemporary disturbances or historical contingencies? ISME Journal 2:254-264

Ge Y, Zhang JB, Zhang LM, Yang M, He JZ (2008b) Long-term fertilization regimes and diversity of an agricultural affect bacterial community structure soil in northern China. J Soils Sediments 8:43-50

Gruber N, Galloway JN (2008) An Earth-system perspective of the global nitrogen cycle. Nature 451:293-296

Guinto DF, Xu ZH, House APN, Saffigna PG (2000) Assessment of $\mathrm{N}_{2}$ fixation by understorey acacias in recurrently burnt eucalypt forests in subtropical Australia using ${ }^{15} \mathrm{~N}$ isotope dilution techniques. Can J For Res 30:112-121

He JZ, Xu ZH, Hughes J (2005a) Pre-lysis washing improves DNA extraction from forest soils. Soil Biol Biochem 37:2337-2341

He JZ, Xu ZH, Hughes J (2005b) Soil fungal communities in adjacent natural forest and hoop pine plantation ecosystems as revealed by molecular approaches based on 18S rRNA genes. FEMS Microbiol Lett 247:91-100

He JZ, Xu ZH, Hughes J (2006) Molecular bacterial diversity of a forest soil under different residue management regimes in subtropical Australia. FEMS Microbiol Ecol 55:38-47

He JZ, Shen JP, Zhang LM, Zhu YG, Zheng YM, Xu MG, Di HJ (2007) Quantitative analyses of the abundance and composition of ammonia-oxidizing bacteria and ammonia-oxidizing archaea of a Chinese upland red soil under long-term fertilization practices. Environ Microbiol 9:2364-2374

He JZ, Zheng Y, Chen CR, He YQ, Zhang LM (2008a) Microbial composition and diversity of an upland red soil under longterm fertilization treatments as revealed by culture-dependent and culture-independent approaches. J Soils Sediments 8:349358

He Y, Xu ZH, Chen CR, Burton J, Ma Q, Ge Y, Xu JM (2008b) Light fraction and macroaggregate associated organic matters as early indicators for management-induced changes of soil in adjacent native and plantation forests of subtropical Australia. Geoderma 147:116-125

Heimann M, Reichstein M (2008) Terrestrial ecosystem carbon dynamics and climate feedbacks. Nature 451:289-292 
Helliker BR, Richter SL (2008) Subtropical to boreal convergence of tree-leaf temperatures. Nature 454:511-514

Horz HP, Barbrook A, Field CB, Bohannan BJM (2004) Ammoniaoxidizing bacteria respond to multifactorial global change. Proc Natl Acad Sci USA 101:15136-15141

Huang ZQ, Xu ZH, Chen CR (2008a) Interactions among soil organic matter fractions, microbial communities and nitrogen transformations in two hardwood plantation of subtropical Australia: effect of mulch. Applied Soil Ecol 40:229-239

Huang ZQ, Xu ZH, Chen CR, Blumfield TJ (2008b) Soil nitrogen mineralization and fate of (15NH4) 2SO4 in field-incubated soil in a hardwood plantation of subtropical Australia: the effects of mulching. J Soils Sediments 8:389-397

Huang ZQ, Xu ZH, Chen CR, Boyd S (2008c) Changes in soil carbon during the establishment of a hardwood plantation in subtropical Australia. For Ecol Manage 254:46-55

Huang ZQ, Xu ZH, Blumfield TJ, Bubb KA (2008d) Foliar $\delta^{13} \mathrm{C}$ and $\delta^{18} \mathrm{O}$ reveal differential physiological responses of canopy foliage to pre-planting weed control in a young spotted gum (Corymbia citriodora subsp. Variegata) plantation. Tree Physiol 28:1535-1543

Huang ZQ, Xu ZH, Blumfield TJ, Bubb KA (2008e) Variations in relative stomatal and biochemical limitations to photosynthesis in a young blackbutt (Eucalypt pilularis) plantation subjected to different levels of weed control. Tree Physiol 28:997-1005

Huang ZQ, Xu ZH, Bubb KA, Blumfield TJ (2008f) Effect of mulching on the growth, foliar photosynthetic nitrogen and water use efficiency of hardwood plantations in subtropical Australia. For Ecol Manage 255:3447-3454

Hui DF, Sims DA, Johnson DW, Cheng WX, Luo YQ (2002) Effects of gradual versus step increases in carbon dioxide on Plantago photosynthesis and growth in a microcosm study. Environ Exp Bot 47:51-66

Hyvönen R, Agren GI, Linder S, Persson T, Cotrufo MF, Ekblad A, Freeman M, Grelle A, Janssens IA, Jarvis PG, Kellomaki S, Lindroth A, Loustau D, Lundmark T, Norby RJ, Oren R, Pilegaard K, Ryan MG, Sigurdsson BD, Stromgren M, van Oijen $\mathrm{M}$, Wallin G (2007) The likely impact of elevated $\left[\mathrm{CO}_{2}\right]$, nitrogen deposition, increased temperature and management on carbon sequestration in temperate and boreal forest ecosystems: a literature review. New Phytol 173:463-480

Johnson CE, Smernik RJ, Siccama TG, Kiemle DK, Xu ZH, Vogt DJ (2005) Using ${ }^{13} \mathrm{C}$ nuclear magnetic resonance spectroscopy for the study of Northern hardwood tissues. Can J For Res 35:18211831

Keeling CD, Mook WG, Tans PP (1979) Recent trends in the ${ }^{13} \mathrm{C} /{ }^{12} \mathrm{C}$ ratio of atmospheric dioxide. Nature 277:121-123

Knicker H (2002) The feasibility of using DCPMAS N-15 C-13 NMR spectroscopy for a better characterization of immobilized N-15 during incubation of C-13- and N-15-enriched plant material. Org Geochem 33:237-246

Knicker H, Fründ R, Lüdemann H-D (1993) The chemical nature of nitrogen in native soil organic matter. Naturwissenschaften 80:219-221

Leininger S, Urich T, Schloter M, Schwark L, Qi J, Nicol GW, Prosser JI, Schuster SC, Schleper C (2006) Archaea predominate among ammonia-oxidizing prokaryotes in soils. Nature 442:806-809

Long SP, Ainsworth EA, Leakey ADB, Nösberger J, Ort DR (2006) Food for thought: lower-than-expected crop yield stimulation with rising $\mathrm{CO}_{2}$ concentrations. Science 312:1918-1921

Magnani F, Mencuccini M, Borghetti M, Berbigier P, Berninger F, Delzon S, Grelle A, Hari P, Jarvis PG, Kolari P, Kowalski AS, Lankreijer H, Law BE, Lindroth A, Loustau D, Manca G, Moncrieff JB, Rayment M, Tedeschi V, Valentini R, Grace J (2007) The human footprint in the carbon cycle of temperate and boreal forests. Nature 447:848-850
Mao XA, Xu ZH, Luo RS, Mathers NJ, Zhang YH, Saffigna PG (2002) Nitrate in soil humic acids revealed by nitrogen-14 nuclear magnetic resonance spectroscopy. Aust J Soil Res 40:717-726

Mathers NJ, Mao XA, Xu ZH, Saffigna PG, Berners-Price SJ, Perera MCS (2000) Recent advances in applications of ${ }^{13} \mathrm{C}$ and ${ }^{15} \mathrm{~N}$ NMR spectroscopy to soil organic matter studies. Aust J Soil Res 38:769-787

Mayewski P, Whitlow S (1996) Snow pit and ice core data from Southern Greenland, 1984. National Snow and Ice Data Centre, Boulder, CO

Oren R, Ellsworth DS, Johnsen KH, Phillips N, Ewers BE, Maier C, Schafer KVR, McCarthy H, Hendrey G, McNulty SG, Katul GG (2001) Soil fertility limits carbon sequestration by forest ecosystems in a CO2-enriched atmosphere. Nature 411:469-472

Pan KW, Xu ZH, Blumfield TJ, Tutua S, Lu MX (2008) In situ mineral ${ }^{15} \mathrm{~N}$ dynamics and fate of added ${ }^{5} \mathrm{NH}_{4}^{+}$in hoop pine plantation and adjacent native forest of subtropical Australia. J Soils Sediments 8:398-405

Penninckx V, Meerts P, Herbauts J, Gruber W (1999) Ring width and element concentrations in beech (Fagus sylvatica L.) from a periurban forest in central Belgium. For Ecol Manage 113:23-33

Piao SL, Ciais P, Friedlingstein P, Peylin P, Reichstein M, Luyssaert S, Margolis H, Fang JY, Barr A, Chen AP, Grelle A, Hollinger DY, Laurila T, Lindroth A, Richardson AD, Vesala T (2008) Net carbon dioxide losses of northern ecosystems in response to autumn warming. Nature 451:49-52

Prasolova NV, Xu ZH (2003) Genetic variation in branchlet nutrient concentrations at different canopy positions in relation to branchlet $\delta 13 \mathrm{C}$ and $\delta 18 \mathrm{O}$ and tree growth of $8-9$ years old hoop pine families in two contrasting growing environments. Tree Physiol 23:675-684

Prasolova NV, Xu ZH, Farquhar GD, Saffigna PG, Dieters MJ (2000) Variation in canopy $813 \mathrm{C}$ of 8 -year-old hoop pine families (Araucaria cunninghamii) in relation to canopy nitrogen concentration and tree growth in subtropical Australia. Tree Physiol 20:1049-1055

Prasolova NV, Xu ZH, Farquhar GD, Saffigna PG, Dieters MJ (2001) Canopy carbon and oxygen isotope composition of 9-year-old hoop pine families in relation to seedling carbon isotope composition and growth, field growth performance and canopy nitrogen concentration. Can J For Res 31:673-681

Prasolova NV, Xu ZH, Lundkivst K (2005) Genetic variation in foliar nutrient concentration in relation to foliar carbon isotope composition and tree growth in clones of the $F_{1}$ hybrid between slash pine and Caribbean pine. For Ecol Manage 210:172-191

Pu GX, Saffigna PG, Xu ZH (2001) Denitrification, leaching and immobilisation of ${ }^{15} \mathrm{~N}$-labelled nitrate in winter under windrowed harvesting residues in 1 to 3 -year-old hoop pine plantations of subtropical Australia. For Ecol Manage 152:183-194

$\mathrm{Pu}$ GX, Xu ZH, Saffigna PG (2002) Fate of ${ }^{15} \mathrm{~N}$-labelled nitrate in a wet summer under different harvesting residue management regimes in young hoop pine plantations. For Ecol Manage 170:285-298

Pu GX, Saffigna PG, Xu ZH (2005) Denitrification, leaching and immobilisation of added ${ }^{15} \mathrm{~N}$ under different residue management regimes in a young hoop pine plantation of subtropical Australia. J Trop For Sci 17:372-385

Reich PB, Hobbie SE, Lee T, Ellsworth DS, West JB, Tilman D, Knops JMH, Naeem S, Trost J (2006) Nitrogen limitation constrains sustainability of ecosystem response to $\mathrm{CO}_{2}$. Nature 440:922-925

Saurer M, Siegwolf RTW, Schweingruber FH (2004) Carbon isotope discrimination indicates improving water-use efficiency of trees in northern Eurasia over the last 100 years. Glob Change Biol 10:2109-2120 
Savard MM, Bégin C, Parent M, Smirnoff A, Marion J (2004) Effects of smelter sulfur dioxide emissions: a spatiotemporal perspective using carbon isotopes in tree rings. J Environ Qual 33:13-26

Seguin V, Gagnon C, Courchesne F (2004) Changes in water extractable metals, $\mathrm{pH}$ and organic carbon concentrations at the soil-root interface of forested soils. Plant Soil 260:1-17

Shen JP, Zhang LM, Zhu YG, Zhang JB, He JZ (2008) Abundance and composition of ammonia-oxidizing bacteria and ammoniaoxidizing archaea communities of an alkaline sandy loam. Environ Microbiol 10:1601-1611

Treydte KS, Schleser GH, Helle G, Frank DC, Winiger M, Haug GH, Esper J (2006) Twentieth century was the wettest period in northern Pakistan over the past millennium. Nature 440:1179 1182

$\mathrm{Xu} \mathrm{ZH}$, Chen CR (2006) Fingerprinting global climate change and forest management within rhizosphere carbon and nutrient cycling processes. Environ Sci Pollut Res 13:293-298

Xu ZH, Myers RJK, Saffigna PG, Chapman AL (1993a) Nitrogen cycling in leucaena (Leucaena leucocephala) alley cropping in semi-arid tropics. II. Response of maize growth to addition of nitrogen fertilizer and plant residues. Plant Soil 148:73-82

Xu ZH, Saffigna PG, Myers RJK, Chapman AL (1993b) Nitrogen cycling in leucaena (Leucaena leucocephala) alley cropping in semi-arid tropics. I. Mineralization of nitrogen from leucaena residues. Plant Soil 148:63-72

Xu ZH, Saffigna PG, Farquhar GD, Simpson JA, Haines RJ, Walker S, Osborne DO, Guinto D (2000) Carbon isotope discrimination and oxygen isotope composition in clones of the $\mathrm{F}_{1}$ hybrid between slash pine (Pinus elliottii) and Caribbean pine ( $P$. caribaea) in relation to tree growth, water-use efficiency and foliar nutrient concentration in subtropical Australia. Tree Physiol 20:1209-1217

Xu ZH, Prasolova NV, Lundkvist K, Beadle C, Leaman T (2003) Genetic variation in carbon and nitrogen isotope composition and nutrient concentration in the foliage of 10-year-old hoop pine families in relation to tree growth in subtropical Australia. For Ecol Manage 186:359-371

Xu QF, Jiang PK, Xu ZH (2008a) Soil microbial functional diversity under intensively managed bamboo plantations in southern China. J Soils Sediments 8:177-183

$\mathrm{Xu} \mathrm{ZH}$, Ward S, Chen CR, Blumfield T, Prasolova NV, Liu JX (2008b) Soil carbon and nutrient pools, microbial properties and gross nitrogen transformations in adjacent natural forest and hoop pine plantations of subtropical Australia. J Soils Sediments 8:99105

Zhang L, Xu ZH (2008) Assessing bacterial diversity in soil: a brief review. J Soils Sediments 8:379-388

Zhao W, Cai ZC, Xu ZH (2007) Does ammonium-based N addition influence nitrification and acidification in humid subtropical soils of China? Plant Soil 297:213-221

Zheng Y, Zhang LM, Zheng YM, Di HJ, He JZ (2008) Abundance and community composition of methanotrophs in a Chinese paddy soil under long-term fertilization practices. J Soils Sediments 8:406-414 